\title{
Qualitative Analysis of the Perception of Company Managers in Knowledge Management in the Maintenance Activity in the Era of Industry 4.0
}

\author{
Javier Cárcel-Carrasco ${ }^{1, *(1)}$ and Consuelo Gómez-Gómez ${ }^{2}$ (D) \\ 1 Department of Architectural Constructions, Universitat Politècnica de València, Camino de Vera $\mathrm{s} / \mathrm{n}$, \\ 46022 València, Spain \\ 2 Sociedad de Agricultores de la Vega de Valencia, S.A, Universitat Politècnica de València, \\ Camino de Vera s/n, 46022 València, Spain; magogo@doctor.upv.es \\ * Correspondence: fracarc1@csa.upv.es; Tel.: +34-963877000
}

Citation: Cárcel-Carrasco, J.; Gómez-Gómez, C. Qualitative Analysis of the Perception of Company Managers in Knowledge Management in the Maintenance Activity in the Era of Industry 4.0. Processes 2021, 9, 121. https:// doi.org/10.3390/pr9010121

Received: 4 December 2020 Accepted: 5 January 2021 Published: 8 January 2021

Publisher's Note: MDPI stays neutral with regard to jurisdictional clai$\mathrm{ms}$ in published maps and institutional affiliations.

Copyright: (C) 2021 by the authors. Licensee MDPI, Basel, Switzerland. This article is an open access article distributed under the terms and conditions of the Creative Commons Attribution (CC BY) license (https:// creativecommons.org/licenses/by/ $4.0 /)$.

\begin{abstract}
In industrial maintenance activity, very sophisticated technical and human factors are needed to achieve the great process or service that the company provides, with a large dose of knowledge based on the personal experience of maintenance technicians. However, the management and application of knowledge in this activity is often relegated to a third level (or simply forgotten). The aim of this study is to identify, classify and prioritize the different barriers and facilitators that can be found in maintenance organizations of the company in reference to knowledge management in strategic maintenance activities, and what competitive advantages could be used for their appropriate introduction in the company. For this, qualitative techniques have been used through a field study and observation, as well as semi-structured interviews between company directors and maintenance managers of first-level companies in various sectors (industrial or services), to draw conclusions on the application of knowledge management techniques which help to determine the principles of a company that wants to face a knowledge management project within the area of maintenance engineering.
\end{abstract}

Keywords: knowledge management; industrial maintenance; tacit knowledge; large building maintenance; industry 4.0

\section{Introduction}

"Knowledge management" (KM) is an emerging discipline that is being affirmed with the appearance of some new paradigms in national and international economic systems [1-4] and introduced in an incipient way into the global aspects of companies, assuming what has been called an "economy based on knowledge and learning" [5,6], where knowledge is intensified as the axis of change and innovation [7-11].

The concept of Industry 4.0 will generate new techniques, services, and products, increasing productivity and generating new qualified jobs in the industry. Faced with this transformation, people from all departments of the industry must have new skills and competencies to work in Industry 4.0. This will require a qualification and knowledge management for companies [12,13]. Maintenance departments within companies operate with technicians with high knowledge based on their professional experiences, with a high component of tacit knowledge, and traditionally with no knowledge on management policies [14,15].

The relation between the philosophy of Industry 4.0 and the maintenance department of the companies with large buildings and high physical assets are very important, for aspects as updating, efficiency and monitoring the resources, and for the exchange and interaction capacities between person, machines, and facilities. All this should promote the development of capacities allowing companies to adapt to future changes. All this 
leads to the need of proper knowledge management which should be incorporated in the philosophy of Industry 4.0. [16-19].

The industrial maintenance activity depends on highly sophisticated technical and knowledge components, and a high involvement of the human factor in its performance, along with a high component of tacit knowledge. Although organizational factors, behaviour of materials, and failure are widely studied, they are not usually the same as the knowledge management processes mentioned, although in other departments of the company (marketing, commerce, development, communications, etc.), they are increasingly recognised as a benchmark of competitiveness and innovation [20-23].

Proper knowledge management must connect and transmit the information among departments of the company, between its facilities, devices, and systems along with the maintenance technicians themselves [24-27]. The proposed solutions in the new generation of maintenance models seek to generate analysis systems in order to help professionals make decisions and solve problems $[28,29]$. Is crucial to reduce maintenance interventions and unscheduled breakdowns, based on the study of the data collected from the systems and the acquired knowledge by the people who operate these facilities [30-33]. These measures can predict the occurrence of a breakdown, repair or downtime due to critical malfunction which can imply significant costs to the company.

Therefore, the solutions of Industry 4.0 should allow companies to implement preventive maintenance and actions to improve the reliability and troubleshooting, energy efficiency improvement and normal actions of the operations of the facilities [34]. The maintenance technicians can improve the cycle and adjust the monitoring parameter of maintenance, with knowledge management policies that capture and transfer this strategic knowledge (normally tacit) which is gained by the people who are in these departments based in their experience acquired after years of working in the company.

The concept of Industry 4.0, big data, and predictive maintenance (PdM) are closely related. The PdM relies on monitoring machinery in order to optimize the maintenance tasks so that the repair tasks are only executed when they are strictly necessary $[26,34,35]$.

Therefore, the starting point is the visualization of this resource as a strategic and significant element [36]; in any approach oriented to the efficient development of a maintenance department, and therefore of the company itself.

It must be considered that organizations should be studied through their internal processes, visualizing how they create and transfer knowledge, and identifying the stock of knowledge they own and how it is used to generate new knowledge [37-40], and within a company, maintenance is a sub-organization, with special features and high importance regarding sustainability and productivity of the company.

Thus, all the theoretical contributions of knowledge management have a point in common: analysing organizations from a perspective based on the knowledge they own [41], how to transfer and how to use them.

That is why it is of vital importance to define and extract the mechanisms of structural coordination, facilitators, and creation of knowledge [42] which occur in a maintenance organization, which induce an improvement in its operational processes, an activity to innovation $[43,44]$, transmitting an improvement throughout the whole company and thus a management of human resources towards the achievement of knowledge management [45] with a useful and productive purpose.

The reliability of the machines or systems requires a high level of knowledge and experience and is closely linked to the study of the failure process, associating the aspects of reliability and quality in the service provided by maintenance [46-51], making it possible to establish new indicators that allow estimating the security level of these systems, in which the impact on infrastructure and associated risks is described [52].

It must be taken into account that the main factors that determine the operational reliability (of a human and technical nature) of the maintenance activity include the following [53-55]. Operational activities (also called facilities management) are the normal processes that occur in the course of the production or service provided by the company, 
which involve the manoeuvre of the facilities, rearming of switches, start-up manoeuvres, or stoppage process, etc.

Within the tactical context of maintenance, if we define knowledge management as a process to be taken into account within mentioned activity, such an approach could basically be integrated by the generation, codification, transfer, and use of knowledge [56-58].

This article contains the results of the study aimed to define a frame of reference that would allow understanding and addressing the knowledge management within maintenance activities, visualizing the fundamental tactical actions that are performed in the company environment, as well as extracting the fundamental barriers and facilitators that would make a service more efficient with the design of work strategies based on the creation, transmission and use of knowledge. Through the use of qualitative research techniques, the vision from the management of the companies and the maintenance managers regarding the knowledge management in these departments is shown. For this purpose, interviews have been carried out with company executives and maintenance managers or heads of various companies, from different sectors in Spain.

\section{Materials and Methods}

The research has focused on two fundamental aspects, in order to describe the feelings, concerns and characteristics in which the knowledge management processes are developed in maintenance engineering, through the perception of the management bodies of companies and by own headquarters of the maintenance organization.

In qualitative research [59], being objective does not mean controlling variables but being open, having the will to listen and to "give voice" to the interviewees, being the individuals or organizations. It means hearing what others have to say, and seeing what others do, and representing them as precisely as possible. At the same time, it means understanding and recognizing what researchers know which is usually based on the values, culture, education and experiences which they bring to research situations and that it can be very different from their interviewees.

Within qualitative techniques, grounded theory $[60,61]$ has been used in the analysis of research data. For this, the process indicated by Charmaz [60] has been followed:

- Data collection through theoretical sampling.

- Initial coding.

- Oriented coding.

- Elevation of the codes to provisional categories by theoretical coding.

- Writing the results obtained.

The fundamental characteristic of the research with grounded theory is the theoretical sampling procedure, where cases must be selected based on their potential for the development of new points of view and refinement of those already obtained [62].

As results of the application of the grounded theory, the following should be obtained [63]:

- The exposition of the main variables that explain how the studied group solve their problems.

- The results and the basic processes which people use to solve the key problems.

- It is not enough to describe the phenomenon. It is necessary to go one step further and come to interpret and explain what is happening.

With observation techniques, an attentive examination of the different aspects of a phenomenon is carried out in order to study its characteristics and behaviour within the environment in which it develops. It is a technique that consists of observing the fact or case, taking information, and recording it for subsequent analysis.

Direct observation of a phenomenon helps to make the appropriate approach to the problem to be studied. Additionally, among many other advantages, it allows a global formulation of the research, including its plans, programs, techniques, and tools to be used. 
Through case studies, it is possible to analyse the phenomenon under study in its real context, using multiple sources of evidence, quantitative and/or qualitative simultaneously. On the other hand, this implies the use of abundant subjective information, the impossibility of applying statistical inference and a high influence of the subjective judgment of the researcher in the selection and interpretation of the information.

The case study method is a valuable research tool, and its greatest strength lies in the fact that it measures and records the behaviour of the people involved in the phenomenon studied [64].

The characteristics of each phase of the investigation to achieve the defined objectives can be summarized as follows:

(a) In the first phase, the discussion group was used, with the participation of five experts in the industrial maintenance activity with more than 20 years of experience in that environment, in order to reach a consensus on the research questions to be used by applying grounded theory. It was used to mark the fundamental factors in industrial maintenance engineering, in relation to the factors involved in the knowledge management processes regarding operation-exploitation, reliability and energy efficiency. Five industrial maintenance experts from different companies participated. The panel served to mark the processes of a maintenance model based on knowledge management techniques, as well as general questionnaires and surveys that were used to capture the primary information at the beginning of the investigation.

(b) Subsequently, and in order to focus the research on a company that meets the optimal conditions of the study, and to mark the conditions in which knowledge management influences within companies, a case study was carried out with the support of direct observation techniques and interviews with the people in charge, so that the general conditions of their maintenance departments, their fundamental strategic actions, and their general relationship with knowledge management and its utility could be detected first-hand. Prior to field research at the factory. Ten companies in the industrial or service area were carried out in their maintenance activities. The companies have been selected according to the fact that they had high physical, productive, or large facilities assets and with maintenance departments responsible for their operation. For this purpose, the different sectors were selected in order to have a wider vision of the activities carried out by maintenance staff. It served to make the determination of the global characteristics that affect all the companies in the maintenance environment, as well as the selection of the company where the field research could be carried out. Specifically, the activities or sectors of the companies visited for the study, in total 10 (Table 1), belong to the following activities:

- 3 companies in the food industrial sector.

- 1 company in the manufacturing industrial sector.

- 1 company in the electrical energy distribution sector.

- 1 company that distributes sanitary water to towns.

- 2 tertiary service companies (Hotels).

- 1 tertiary service company (Large shopping centre).

- 1 company outsourced maintenance services.

Through the case study and direct observation of the 10 companies, one of them was selected in order to focus the investigation and deepen its internal operational characteristics of its maintenance departments. The criteria for selecting the company to deepen the study were as follows:

- Company with a high component of critical elements.

- Have several factories or work areas in different populations.

- Consolidated maintenance departments.

- Availability and ease to do the research. 
Table 1. Characteristics of the sample companies.

\begin{tabular}{|c|c|c|}
\hline Company & Fundamental Features & Observations \\
\hline Company 1 & $\begin{array}{ll}\text { - } & \text { Total company staff: } 1230 \text { people } \\
\text { - } & \text { Maintenance staff: } 230 \text { people } \\
\text { - } & \text { Main activity: Food industry sector (Production of meat } \\
\text { products packed in crude oil) } \\
\text { - } \quad \text { Implementation area: National level, three factories } \\
\text { distributed in Spain. }\end{array}$ & $\begin{array}{l}\text { - Great needs for reliability and subject to } \\
\text { strict sanitary regulations. } \\
\text { High number of critical technical facilities } \\
\text { oriented towards the production of meat } \\
\text { products. } \\
\text { Various specialized maintenance sections } \\
\text { with their own personnel. }\end{array}$ \\
\hline
\end{tabular}

\begin{tabular}{|c|c|c|}
\hline Company 2 & $\begin{array}{ll}\text { - } & \text { Total company staff: } 360 \text { people } \\
\text { - } & \text { Maintenance staff: } 45 \text { people } \\
\text { - } & \text { Main activity: Food industry sector (Production of } \\
\text { - } & \text { precooked products) } \\
\text { Implantation zone: Regional level, (Valencian } \\
\text { Community-Spain). }\end{array}$ & $\begin{array}{l}\text { - } \quad \text { Subjected to strict sanitary regulations. } \\
\text { The unscheduled shutdown of the } \\
\text { production process involves large } \\
\text { indirect losses. }\end{array}$ \\
\hline Company 3 & $\begin{array}{ll}\text { - } & \text { Total company staff: } 340 \text { people } \\
\text { - } & \text { Maintenance staff: } 15 \text { people } \\
\text { - } & \text { Main activity: Food industry sector (Production of meat } \\
\text { - } & \text { Sausages) } \\
\text { Implantation zone: Regional level, (Valencian } \\
\text { Community-Spain). }\end{array}$ & $\begin{array}{l}\text { - } \quad \text { Subjected to strict sanitary regulations. } \\
\text { - The unscheduled shutdown of the } \\
\text { production process involves large } \\
\text { indirect losses. }\end{array}$ \\
\hline Company 4 & $\begin{array}{ll}\text { - } & \text { Total company staff: } 290 \text { people } \\
\text { - } & \text { Maintenance staff: } 11 \text { people } \\
\text { - } & \text { Main activity: Industrial sector (Production of sanitary } \\
\text { - } \quad \text { Implainers) } & \\
\text { Implentation area: International level, (Valencian } \\
\text { Community-Spain). }\end{array}$ & $\begin{array}{l}\text { Industrial production and security } \\
\text { requirement increased by the } \\
\text { characteristics of the production process. }\end{array}$ \\
\hline Company 5 & $\begin{array}{ll}\text { - } & \text { Total company staff: } 11,000 \text { people } \\
\text { - } & \text { Maintenance and operation staff: } 4100 \text { people } \\
\text { - } & \text { Main activity: Production, distribution and sale of } \\
\text { electrical energy } \\
\text { - } \quad \text { Implementation area: International level }\end{array}$ & $\begin{array}{l}\text { - Maintenance and operation of high and } \\
\text { low voltage electrical networks. } \\
\text { Although the scope of the company is } \\
\text { international, the study has focused on a } \\
\text { sector or area of action of the company. }\end{array}$ \\
\hline Company 6 & $\begin{array}{l}\text { - } \quad \text { Total company staff: } 900 \text { people } \\
\text { - } \quad \text { Maintenance and operation staff: } 400 \text { people } \\
\text { - } \quad \text { Main activity: Supply and distribution of drinking water } \\
\text { to populations. } \\
\text { - Implantation zone: Regional level, (Valencian } \\
\text { Region-Spain). }\end{array}$ & $\begin{array}{l}\text { Maintenance and operation of drinking } \\
\text { water distribution networks to } \\
\text { populations. }\end{array}$ \\
\hline Company 7 & $\begin{array}{ll}\text { - } & \text { Total company staff: } 6 \text { people } \\
\text { - } & \text { Maintenance staff: } 6 \text { people } \\
\text { - } & \text { Main activity: Commercial premises. } \\
\text { - } \quad \text { Implantation zone: Regional level, (Valencian } \\
\text { Region-Spain). }\end{array}$ & $\begin{array}{l}\text { - Technical facilities oriented to the various } \\
\text { commercial premises located in the center } \\
\text { and their common services. } \\
\text { Reduced own staff. Maintenance } \\
\text { personnel are subcontracted to external } \\
\text { companies }\end{array}$ \\
\hline
\end{tabular}

$\begin{array}{lll} & - & \text { Total company staff: } 68 \text { people } \\ & - & \text { Maintenance staff: } 15 \text { people } \\ \text { Company } 8 & - & \begin{array}{l}\text { Main activity: Electrical installations, manufacture of } \\ \text { electrical panels and subcontracted maintenance services }\end{array} \\ & - & \begin{array}{l}\text { Implantation zone: Regional level, (Valencian } \\ \text { Region-Spain). }\end{array}\end{array}$

- Maintenance services subcontracted to various companies. 
Table 1. Cont.

\begin{tabular}{|c|c|c|}
\hline Company & Fundamental Features & Observations \\
\hline Company 9 & $\begin{array}{ll}\text { - } & \text { Total company staff: } 22 \text { people } \\
\text { - } & \text { Maintenance Staff: } 5 \text { people } \\
\text { - } & \text { Main activity: Hotel services. } \\
\text { - } & \text { Implantation zone: Regional level, (Valencian } \\
& \text { Region-Spain). }\end{array}$ & $\begin{array}{l}\text { - Technical facilities aimed at providing } \\
\text { quality service to the rooms and services } \\
\text { of a 4-star hotel. } \\
\text { Mixed, own and subcontracted } \\
\text { maintenance personnel. }\end{array}$ \\
\hline Company 10 & $\begin{array}{ll}\text { - } & \text { Total company staff: } 35 \text { people } \\
\text { - } & \text { Maintenance staff: } 5 \text { people } \\
\text { - } & \text { Main activity: Hotel services } \\
\text { - } & \text { Area of implantation: Regional level, (Valencian } \\
& \text { Region-Spain). }\end{array}$ & $\begin{array}{l}\text { - Technical facilities aimed at providing } \\
\text { quality service to the rooms and services } \\
\text { of a 5-star hotel. } \\
\text { Mixed, own and subcontracted } \\
\text { maintenance personnel. }\end{array}$ \\
\hline
\end{tabular}

Even though companies may have important difference regarding the number of employees that work in maintenance department, all of them usually have same type of fundamental operations assigned to them (maintainability, reliability, energy efficiency and troubleshooting). The companies with large staff in maintenance department (e.g., electricity production and distribution companies), actually they operate with maintenance groups working in different areas that can range from 20 to 30 technicians. Likewise, it can be commented the industrial companies with hundreds of employees, however their groups are distributed at different timetables and areas which involve smaller groups. It has also been proved that companies with small maintenance staff (e.g., hotels) are assigned to the same core mission as the rest of the companies. Thus, the general aspects of the study should not vary considerably as there is a significant variation in the number of employees, since the strategic activities assigned to the maintenance department are often the same.

Specifically, company No. 1 was selected, given the high volume of facilities and technical equipment available to it, with a large staff of maintenance and work in an environment of requirements to achieve the required production. As well as awareness and facilities to carry out the research. It is a first-rate company dedicated to the food sector with a total staff of 1137 employees distributed in three locations and a maintenance group of 230 people.

(c) In the third phase and using grounded theory, 32 people belonging to management personnel of the companies analysed were interviewed. In order to obtain information that is not conditioned by the responses of the interviewees, a semi-structured indepth interview protocol is followed with a flexible style, to extract and understand the experiences from the interviewee's perspective, all of them belonging to the management of the company.

The format of the questions for the individual interview is based on ten basic questions, the script of the interview being as follows:

- The aim is to study the factors that intervene in Knowledge Management in maintenance engineering within the company. Based on your personal experience, answer the following questions:

- B01. What policies does the company have on strategic knowledge management? How is management involved?

- B02. Are there strategies to capture and use knowledge? Does it include maintenance departments?

- B03. What barriers or facilitators do you think would be important in a KM project? What do you think management could do to improve it?

- B04. Has a knowledge audit been carried out? Have knowledge maps been created or used to clarify knowledge flows, within the most important tactical activities? 
- B05. What is demanded by the management of the company to the maintenance department? Do you consider the knowledge and information handled by the maintenance department important? What influences the company?

- B06. What particularities do you see occurring among the maintenance staff? Is their renovation easy?

(d) In the fourth phase, using the discussion group technique, in a preliminary process, before delving into the maintenance managers or managers. It started with a selected group of 12 people, responsible for the different maintenance sections of the company. There are 12 people, belonging to different maintenance areas (Mechanics, electrical, systems, production machinery, technical office), in a relaxed environment and with the presence of the researcher as moderator, using some guiding questions used. The format of the open guide questions to discuss were:

- D01. What are the success aspects of the functions that each of the maintenance areas performs towards the company?

- D02. How can strategic actions be improved with adequate knowledge management?

- D03. What type of knowledge is related to each of the strategic maintenance activities?

- D04. How can knowledge capture, transmission and utilization processes be improved among operational technicians, and what would improve the efficiency of maintenance processes?

- D05. What means or tools would be adequate to help capture and transmit strategic knowledge?

- D06. What barriers are observed and what facilitators would be necessary to implement a maintenance management project in the maintenance areas?

Data analysis was performed with the help of the Atlas.ti 5.0 application [65-67] from ResearchTalk Inc.

\section{Results}

This section lists the different elements detected that act as barriers and facilitators in knowledge management in relation to the incidence in strategic maintenance actions. It will be commented firstly from the general vision of the company management, subsequently going through the maintenance organization itself.

\subsection{The Perception of Company Management}

\subsubsection{KM Policies and Company Involvement}

It is established by all of the interviewees that the involvement of the company's management bodies is a key element for the implementation and maintenance of knowledge management projects. The support of the management is also essential for the continuity of the promoted projects and their sustainability.

However, a confusion is detected in eight out of ten companies interviewed about the difference between information management and knowledge management. All companies have adapted or are in the process of coupling, information management policies, mainly focused on administrative areas (administrative procedures, human resources, commercial, purchasing and marketing, etc.), however none of the interviewees, including Considering the importance of maintenance for the sustainability of the company's objectives, it has adopted measures for the introduction in that area. They consider the difficulty of entering that area of the company, where they observe that more expert knowledge nests based on the experience and specialization required for its performance.

\subsubsection{Strategies for Capturing and Using Knowledge}

All the interviewees affirm that it is necessary to formalize strategies for the collection, generation and use of knowledge, which affect the competitiveness of the company. The 
strategies currently used by the companies interviewed, mostly consisting of the use of intranets and periodic or informal meetings with company managers. "Yellow pages" type knowledge maps are formalized, with the names of the people with information and attributions in the different areas of the company.

Documents are the ones that have the greatest impact on the organization when transferring knowledge, but unfortunately there is not enough time to document those activities or actions important for the development of the services provided. Meetings are relevant to the organization as a means of transferring knowledge. These are carried out with some frequency, between the managers and maintenance managers, to adopt global strategies.

It is important to mean the difference between information and knowledge. The information is the recipe, the steps, the order, the quantity, the description; the knowledge can be defined as action, intuition, and an ability acquired through experience.

Thus, the knowledge can be defined as "the ability of people to make decision (or a set of them) which impact will allow us to approach or achieve the agreed targets". The knowledge is gained with practice and through experience. The knowledge is a mixture between "know-how", the experience, the values, and the information. Furthermore, it can be keep updating with more information and with extensive experience.

\subsubsection{Barriers and Facilitators for KM}

Likewise, in this investigation, it has been detected that a proactive attitude of the management, the existence of an organizational culture in the company and that can be transmitted to the maintenance department itself and a motivation of the personnel involved that infuses opportunities to learn, they are important elements in the generation of knowledge. As for the barriers, adjusted templates, the limited availability of time, to be used in actions that are not characteristic of the maintenance activity, the dispersion or non-updating of the necessary information.

\subsubsection{Role of Company Maintenance}

They agree with certain nuances, in the four strategic activities that the maintenance organization must fulfil:

Reliability: It is the fundamental strategic activity for industrial production companies and services for the distribution of electricity and water. Limiting the failure processes, as well as reducing service replacement times in the event of breakdowns is essential due to the high indirect cost passed on to the rest of the company areas. The knowledge of the resolution of breakdowns is critical as it intensely affects the production of the company or the service it provides. There is usually no critical study of reliability or a knowledge map in the face of a crisis. In-depth knowledge of key processes is required.

Maintainability: Everyone considers it as the reason for the maintenance activity, essential to achieve the availability of equipment and facilities and extend the life cycle of machinery and facilities. In tertiary service companies (hotels, shopping malls), where the highest level of subcontracting of maintenance services is concentrated, it is seen by management more as a legal requirement (regulatory maintenance) than as an opportunity to improving the efficiency of services. There is a unit of operators with more experience and knowledge of the facilities and equipment.

Energy efficiency: The role of surveillance in efficient energy consumption is a fundamental role assigned to maintenance departments. Its economic impact transferred to the price of the final product (in the case of industrial production companies), or on the service provided (tertiary service companies), makes it an important variable to take into account. In-depth knowledge of the facilities and equipment, as well as the characteristics of the production processes used, is necessary to determine the best option for energy efficiency.

Operation/exploitation: The process of knowledge in the routine actions of operation, is characteristic of the facilities of each company and involves a coupling time for maintenance technicians. These operational actions directly affect the efficiency of the processes 
or services provided. All the interviewees agree, that in the face of changes in maintenance personnel or the subcontracted company, there is a loss during the first months of operation until the new staff is recruited, when there is a greater knowledge of the facilities and characteristics demanded by the company. It is recognised that the outsourcing processes mean that the subcontractor company manages a strategic knowledge of the company itself, which is normally lost due to the change or substitution of said company. The outsourcing can affect all types and sizes of companies. Nevertheless, the companies in tertiary sector are in favor of outsourcing the service, normally to reduce staff expenses. In industrial companies, outsourcing is often carried out in maintenance areas where it can affect the production in minor extent. On other occasions, outsourcing is carried out on very technical processes or the processes that require high qualification. They acknowledge that when the subcontracted company is changed or replaced, or the staff variation in these companies, requires a time to adapt, due to the lack of experience in their facilities (because of the fact that the acquired knowledge has not been captured or managed of the subcontracting company that stops providing its services).

\subsubsection{Management's Perception of Maintenance Performance}

All the managers interviewed agree on the relevance of the role of maintenance in the company. However, tertiary service companies are more in favour of outsourcing the service. In industrial companies, subcontracting is carried out more frequently in those maintenance areas that may affect production to a lesser extent. They recognize that it is an activity that requires in-depth technical knowledge, proven experience, and that when faced with the replacement or expansion of personnel, it requires a thorough and complex search.

\subsection{Perception of the Maintenance Organization}

With the discussion group formed by the heads of the different operational maintenance areas, the following conclusions are drawn:

Maintenance success factors: The group agrees that a reduction in production downtime through failure control and operational actions and exploitation manoeuvres is the main requirement of company management. The limitation of energy demand is essential since it directly affects the price of the product produced. Maintainability is the part from which the various actions of the department are focused, and directly influences the rest of the strategic activities, although they consider that corrective maintenance is overused, with the preventive and predictive being directed towards the most critical components.

Knowledge Management: The operation of operating personnel is more widely recognized based on their own (tacit) knowledge. There is a large volume of information (catalogues, manuals, planimetry, work parts, measurements, and quantitative data, etc.), although it is usually unstructured, excessive information that costs to glimpse what is important, and the reluctance of the staff to explain the experiences. Similarly, lack of time, tight staffing and staff reluctance are the main barriers they see.

Improvement of KM processes: The group considers that many of the fundamental actions lose efficiency due to the inadequate transmission of knowledge: Many of the tasks experienced by others are again deduced by different colleagues when the case is presented. This entails a significant inefficiency, which in the event of non-cyclical manoeuvres or failures, produces an increase in the cost of the consequence of the failure, and a longer replacement time.

The KM processes could be improved, through an awareness of the staff, training aimed at the benefit of these strategies, forming working groups to lighten the strategic information, and very relevant, marking the responsibility and command of the project in a person internal to the department Maintenance (Maintenance Knowledge Manager).

With the semi-structured interviews based on the grounded theory, to 16 operators with different work experiences in the company, the following considerations are extracted. 


\subsubsection{Maintenance Activities}

All interviewees have identified the following as the main strategic activities of the maintenance departments:

- The reliability of physical assets, which affects the production or service strategies to be provided by the company.

- Maintainability, essential to guarantee availability and increase the life cycle of equipment and facilities.

- The operation/exploitation of the equipment and facilities related to the manoeuvres and operational actions that are registered as a basis of demands or service needs.

- Energy efficiency, as an economic and environmental value that affects other activities.

\subsubsection{Experience and Knowledge Use}

They recognize that in their daily activity, the basis of their actions is based on their own experiences (extracted on numerous occasions in the trial-error-success procedure). The internalization of knowledge is carried out through comments on the experiences of other colleagues, through informal meetings, all having gone through a phase of knowledge osmosis among colleagues with greater experience and who know the company's facilities to a great extent. The less experienced operators recognize that there is a long coupling time within the company in its incorporation period.

The explicit documentation existing in the organization is used cautiously, and only when faced with critical actions is it consulted, observing a great disestablishment of all the information.

Normally the experiences are documented in a very brief way in the daily work parts, as it is a time justification system, rather than to collect or fundamental the important actions carried out that serve the rest of the colleagues in the organization.

\subsubsection{Strategies for Using Knowledge in Maintenance}

No knowledge management program has been implemented within the maintenance organization. If systems are applied to manage the implemented documentation (work parts) and for the IT management of maintenance through IT management programs (periods, materials, time, preventive maintenance, etc.). All of them consider the convenience of structuring the volume of information of the organization, in order to highlight what is important and what is normally used, have block diagrams and system failures for a global and rapid overview of the processes, as well as detailing experiences in a detailed way with the inclusion of explanatory photos and videos, which support the entire team from the experiences of others.

The intranet as well as the use of electronic mail is used to transfer knowledge by the maintenance managers. Maintenance technicians, since they normally carry out manual trade jobs, usually do not have an individual computer position, using a collective service where the data of the actions carried out or work parts are entered and with access to the intranet as a whole. On many occasions, there is no clear definition of what the Intranet houses and for some employees it is easier to access their own sources of knowledge.

\subsubsection{Barriers and Facilitators for Maintenance KM}

The fundamental barriers identified for the adequate management of knowledge have been the limited availability of time to properly document important actions, the cultural barriers with a culture based on "own knowledge", not shared, especially among operational technicians (with a high tacit knowledge component and therefore not registered), as well as getting the full involvement of staff, and the availability of time, are the localized barriers.

Training is considered an important facilitator. They consider that training aimed at their own working environment (more than generic courses), is the one that can give the most use to their way of learning, and with direct application to company problems. They normally use self-learning, as motivation and improvement for their performance. 
A proactive and participatory management style that promotes the emergence of new ideas and work processes, encourages the collaboration of the maintenance group, and encourages to share the knowledge and communicate to members of the organization. The participatory management must be based on the use of upstream communication channels from workers to management. The Management has to provide, evaluate and, if necessary, implement the improvement initiatives received through these channels. Thus, it is very important the involvement (not only from the maintenance technicians) of people that is on management positions of the company and the maintenance services. The participatory management intend to utilize the creativity that is on all levels of the organization and to specify in innovation, that is, an improvement of processes or the performance of resources which is a competitive advantage. In maintenance departments it can have positive effects such as: (a) to reinforce the involvement of the staff in the organization's goals; (b) increase the commitment and responsibility of workers; (c) improve the work environment; (d) promote innovation; (e) loyalty to workers.

Establishing one or several people (Maintenance Knowledge Manager) who coordinate, lead and standardize the way of collecting and managing knowledge, all consider them as the basis for monitoring the project. These coordinators, they consider, must belong to the department itself and with a deep knowledge and experience of the characteristics in which the work is carried out and the vision of the fundamental problems.

The knowledge manager figure in maintenance must be a person with technical, organizational and knowledge management notions, with extensive experience in operational area (who has in-depth knowledge and knows at first hand the factors that influence in maintenance tasks), and which combines all the efforts of the maintenance organization. Their dedication can be partial or total (depending on the characteristics of the company), sharing it with the dedication in other aspects of the maintenance area, while being able to link with the rest of the organization (production, administration, etc.) which would help to improve the provided maintenance service quality.

\subsubsection{Resources, Tools, and Means}

The need for the figure of a "knowledge manager" is confirmed, as an important facilitator in capturing the transfer and use of knowledge. This figure should be a person with technical, organizational training and knowledge management notions, with extensive experience in the operational maintenance area (who knows first-hand the factors that influence their work), and who brings together all efforts of the maintenance organization to manage strategic knowledge that can be used by the entire organization.

Resources should not only be financial, but also personnel resources. In addition, knowledge management should be considered as a workload (with a greater incidence in its beginnings), that is, a weekly time should be reserved to develop the activities to formalize the knowledge management model, as part of the daily tasks.

The endowment of resources is closely linked to the involvement of the operators. If the management does not provide resources to implement the improvements proposed by the operators, they feel that management abandons the commitment to the QA project, the involvement of the operators declining.

Similarly, they consider that the audits (maintenance, knowledge, energy, etc.), used on a few occasions, show that the application of these techniques would enhance, in a first process, the elaboration of a global knowledge management strategy.

They confirm that the characteristics that the technological platform used for knowledge management should have must have simple and agile mechanisms that allow them to quickly and efficiently share their experiences that generate knowledge.

Self-learning based on the information and knowledge of the rest of the operators, is considered as a facilitator that would greatly help to acquire security in the resolution and avoid action and coupling times in the experience of carrying out actions. 


\subsubsection{The Perception towards Management}

Most of the interviewees consider that management involvement is essential. A knowledge management project must be promoted by the maintenance department, with the involvement and endowment of the company's management. They comment that many of the variables that are required for maintenance are conditioned by cost containment and economic results. A KM project is long term and must be understood by management as an improvement investment that will give economic results to the company in the medium or long term.

\section{Discussion}

Through case studies and direct observation of the companies under investigation, important differences are observed in the conception of maintenance, depending on the economic area to which the purposes of the company are dedicated (Table 2).

Table 2. Characteristics observed in the case study in reference to maintenance.

\begin{tabular}{|c|c|c|c|}
\hline Company Cases & $\begin{array}{l}\text { Fundamental Actions } \\
\text { Demanded to Maintenance }\end{array}$ & $\begin{array}{c}\text { Information/Knowledge } \\
\text { Management }\end{array}$ & $\begin{array}{l}\text { Comments from the Direct } \\
\text { Observation of the Case Study }\end{array}$ \\
\hline $\begin{array}{c}\text { Type "Industrial } \\
\text { Production" (No. 1, } \\
2,3,4)\end{array}$ & $\begin{array}{l}\text { Focused on reliability } \\
\text { and prevention of } \\
\text { production stops. } \\
\text { Action in a large } \\
\text { number of critical } \\
\text { technical installations. } \\
\text { production oriented. } \\
\text { Restriction of spending } \\
\text { and financial } \\
\text { containment. }\end{array}$ & $\begin{array}{l}\text { There is more documentation } \\
\text { in the maintenance actions. } \\
\text { On numerous occasions, } \\
\text { excessive documentation, } \\
\text { which makes the consultation } \\
\text { and acquisition of knowledge } \\
\text { ineffective. } \\
\text { The transfer of knowledge in } \\
\text { maintenance is fundamentally } \\
\text { carried out by informal } \\
\text { meetings and experience over } \\
\text { time in the factory. } \\
\text { There is a long coupling } \\
\text { period to achieve the } \\
\text { necessary operability and } \\
\text { knowledge of the operators. }\end{array}$ & $\begin{array}{l}\text { High monitoring of } \\
\text { production departments on } \\
\text { maintenance. } \\
\text { In the face of critical actions, } \\
\text { the effect of "combat } \\
\text { shakedown" is observed, } \\
\text { which denotes insecurity } \\
\text { and lack of procedure in } \\
\text { said actions. } \\
\text { Islands of knowledge are } \\
\text { observed between the } \\
\text { different maintenance areas. } \\
\text { Replenishment of staff is } \\
\text { often costly in finding } \\
\text { suitable candidates. }\end{array}$ \\
\hline $\begin{array}{c}\text { Type "Water or } \\
\text { Energy Distribution } \\
\text { Services" (No. 5, 6) }\end{array}$ & $\begin{array}{l}\text { Focused on the } \\
\text { operation and } \\
\text { manoeuvres of facilities, } \\
\text { and troubleshooting. } \\
\text { Operation with great } \\
\text { dispersion of the } \\
\text { facilities at the territorial } \\
\text { level, which requires a } \\
\text { long coupling time for } \\
\text { the operators. } \\
\text { Service replacement } \\
\text { times directly affect the } \\
\text { economic results of the } \\
\text { company. }\end{array}$ & $\begin{array}{l}\text { Knowledge based on } \\
\text { experience in the } \\
\text { performances. } \\
\text { Newly recruited operators } \\
\text { acquire the necessary } \\
\text { knowledge, accompanying } \\
\text { and observing veteran } \\
\text { operators. } \\
\text { Acquisition of knowledge } \\
\text { based on informal meetings } \\
\text { and telephone conversations. } \\
\text { There is a long coupling } \\
\text { period to achieve the } \\
\text { necessary operability and } \\
\text { knowledge. }\end{array}$ & $\begin{array}{l}\text { Works based on the } \\
\text { experience and tacit } \\
\text { knowledge of the oldest } \\
\text { operators. } \\
\text { Little elaborated work } \\
\text { documentation, using the } \\
\text { operators' own "practical } \\
\text { notebook" of work. } \\
\text { Islands of knowledge are } \\
\text { observed between the } \\
\text { different work areas. } \\
\text { Employees of a territorial } \\
\text { area find it difficult to adapt } \\
\text { to other territorial areas. }\end{array}$ \\
\hline
\end{tabular}


Table 2. Cont.

\begin{tabular}{|c|c|c|c|}
\hline Company Cases & $\begin{array}{c}\text { Fundamental Actions } \\
\text { Demanded to Maintenance }\end{array}$ & $\begin{array}{c}\text { Information/Knowledge } \\
\text { Management }\end{array}$ & $\begin{array}{l}\text { Comments from the Direct } \\
\text { Observation of the Case Study }\end{array}$ \\
\hline $\begin{array}{c}\text { Type "Tertiary } \\
\text { Services" (Hotels, } \\
\text { Shopping Centers) } \\
\text { (No. 7, 9, 10) }\end{array}$ & $\begin{array}{l}\text { Focused on the quality } \\
\text { of the service provided. } \\
\text { Action in a large } \\
\text { number of critical } \\
\text { technical facilities } \\
\text { oriented towards } \\
\text { customer service. } \\
\text { There is a tendency to } \\
\text { subcontract } \\
\text { maintenance services. } \\
\text { Oriented towards legal } \\
\text { maintenance. }\end{array}$ & $\begin{array}{l}\text { Strategic knowledge in the } \\
\text { hands of external companies } \\
\text { (subcontractor). } \\
\text { In many occasions lost or } \\
\text { unstructured documentation, } \\
\text { usually due to little follow-up } \\
\text { by management. } \\
\text { The transfer of knowledge in } \\
\text { maintenance is carried out } \\
\text { abruptly when there is a } \\
\text { change in the subcontractor } \\
\text { company, producing in those } \\
\text { periods loss of operation and } \\
\text { efficiency. }\end{array}$ & $\begin{array}{l}\text { High dependence of the } \\
\text { company on the } \\
\text { subcontractor company. } \\
\text { In the face of critical actions, } \\
\text { the effect of "combat } \\
\text { shakedown" is observed, } \\
\text { which denotes insecurity } \\
\text { and lack of procedure in } \\
\text { said actions. } \\
\text { Management views } \\
\text { maintenance as a source of } \\
\text { expenses. }\end{array}$ \\
\hline $\begin{array}{c}\text { Type } \\
\text { "Subcontracted } \\
\text { Support" for } \\
\text { Maintenance } \\
\text { Services. (No. 8) }\end{array}$ & $\begin{array}{l}\text { Action on the services } \\
\text { demanded by the } \\
\text { company that your } \\
\text { experience requires. } \\
\text { Action on non-critical } \\
\text { work in production } \\
\text { areas. } \\
\text { In tertiary service } \\
\text { companies, all } \\
\text { maintenance work may } \\
\text { be required. }\end{array}$ & $\begin{array}{l}\text { They find large information } \\
\text { gaps when they take over } \\
\text { facilities, in the event of a } \\
\text { subcontractor company } \\
\text { change. } \\
\text { Knowledge in work areas } \\
\text { requires significant } \\
\text { engagement time. } \\
\text { Critical actions and } \\
\text { experience-based work } \\
\text { processes are not normally } \\
\text { documented. }\end{array}$ & $\begin{array}{l}\text { The profitability of the } \\
\text { outsourced service company } \\
\text { is sought, many times, } \\
\text { against the very criteria of } \\
\text { the company that requires } \\
\text { them. } \\
\text { There is a great movement } \\
\text { of personnel. } \\
\text { There is often a lack of } \\
\text { qualification in the driving } \\
\text { staff of the facilities, } \\
\text { possibly due to contained } \\
\text { salaries. }\end{array}$ \\
\hline
\end{tabular}

- There is greater recognition of maintenance by the managers in industrial production companies, with which there is a greater tendency to own personnel, since it directly affects their strategy and efficiency in production.

Observations - In tertiary service companies, there is a tendency for full outsourcing of maintenance services. There is a great dependence on the maintenance subcontractor company. In the face of changes in the company, there is a period of inefficiency until the new subcontractor company is engaged. The strategic knowledge of the company is in the hands of outside companies.

There is greater acknowledgment of maintenance by the managers in industrial production companies, with which there is a greater tendency to own personnel since it directly affects their production strategy and efficiency.

In tertiary service companies, there is a tendency for full outsourcing of maintenance services. There is a great dependence on the maintenance subcontractor company. In the face of changes in the company, there is a period of inefficiency until the new subcontractor company is engaged. The strategic knowledge of the company is in the hands of outside companies.

From qualitative studies it can be deduced that a flexible proactive organizational culture together with a participative management style are elements that allow activities to be carried out both in the generation and in the transfer of knowledge within the organization.

The main characteristics that have been identified in the present study in terms of tools, barriers, and facilitators and implications in knowledge management processes in industrial maintenance engineering from the perspective of the company management and maintenance managers are shown in Table 3. 
Table 3. Tools, barriers and facilitators in knowledge management in maintenance activity from the point of view of the company management.

\begin{tabular}{ll}
\hline Category of The Studyed Phenomenon & \multicolumn{1}{c}{ Business Managers or Maintenance Managers } \\
\hline & Maintenance audits. \\
& Energy audits. \\
Tools for Knowledge Management & Knowledge audits. \\
& Information and knowledge maps. \\
& Criticality diagrams. \\
\hline
\end{tabular}

Criticality diagrams.

Barriers in Knowledge Management

Cultural barriers.

Maintenance staff involvement.

Implication of company management.

Greater use of informal knowledge transfer mechanisms.

Open and flexible proactive organizational culture.

Participatory style of management.

Employee's personal motivation.

Opportunity to learn.

Facilitators in Knowledge Management Organizational culture of the maintenance area.

Physical space

Management style

Media.

Use of a manager of own knowledge of the maintenance activity.

Observations

Everyone believes that awareness and knowledge of the general management is essential to achieve the means and promote improvement in knowledge management and maintenance optimization, with a medium and long-term vision.

- Capture of the tacit strategic knowledge of operational maintenance technicians.

- $\quad$ Resolution of critical failures in less time (especially non-cyclical ones).

- $\quad$ Reduction of operating manoeuvre times.

- $\quad$ Facilitate the change of area or personnel substitutions.

- Reduction of coupling times for new personnel.

Results of Proper Management of Knowledge in Maintenance Activity.
- Capture of information and transfer of subcontractor companies.

- Share knowledge of employees that can be used by others who can detect new opportunities for improvement.

- Improved knowledge of the reliability of equipment and facilities.

- Improvement of knowledge for the detection and improvement of energy efficiency actions.

- $\quad$ Optimization of time, which again results in knowledge management and the reduction of maintenance costs.

Improvement of self-learning to solve problems in the factory itself.

The need for the figure of a "knowledge manager" as an important facilitator in capturing the transfer and use of knowledge is present. This figure should be a person with technical, organizational training and knowledge management notions, with great experience in the operational area (who knows in depth first-hand the factors that influence their work), and who brings together all the efforts of the maintenance organization to manage strategic knowledge that can be used by the entire organization. Their dedication could be partial or total (depending on the characteristics of the company), sharing it with the dedication in other aspects of the maintenance area, and could at the same time link with the rest of the organization (production, administration, etc.), which would help to improve the quality of the maintenance service provided. This suggests that the knowledge to be transferred needs to be a priority within the organization where its transfer needs to be planned like the rest of the company's strategic activities.

On the part of the maintenance managers, it is considered that one of the fundamental barriers found by this study is the limited availability of time to properly document important actions, as well as a culture based on "own knowledge" rarely shared. 
Through this work based on qualitative studies, it is intended that it can serve as basis for future research in order to design a suitable model of knowledge management applied to industrial maintenance departments of the companies, which allows capturing strategic knowledge (normally tacit) which rules in maintenance departments. It would also be interesting to carry out new studies with more companies from different countries and strategic sectors in order to extend and confirm the collected data, since this is the main limitation in this task due to study area which has focused on Spain.

\section{Conclusions}

In this article, a review of the barriers and facilitators for the proper management of knowledge in the maintenance activity in relation to its strategic activities has been made, through the analysis of cases and the direct observation of ten companies and qualitative study through semi-structured interviews with company executives and maintenance managers or managers. The review has been carried out from the point of view of the contribution of information concerning management processes and the problems of implementation in the company, as well as ways to overcome them.

The maintenance activity processes, characterized by a high human factor, with a high degree of tacit knowledge, bring to the introduction of knowledge management techniques topics related to daily performance, such as the reliability of the company, energy efficiency, and maintainability processes, which results in a lower failure rate, a shorter service or availability replacement time, an improvement in the use of energy, and a lowering of the maintenance processes, all of which increase productivity. All this translates into greater overall efficiency of the company, better economic results, and an increase in the useful life of equipment and facilities.

All of the above suggests that the knowledge to be transferred needs to be a priority in the activity of industrial maintenance, that is, it must be included and foreseen in the strategic planning of the company.

This study also aims to provide those responsible for the maintenance of companies with a study that allows companies to know what aspects must be taken into account to implement and sustain a knowledge management model.

Author Contributions: J.C.-C. developed the methodology; J.C.-C. and C.G.-G. prepared the conceptualization and data curation; J.C.-C. gathered and analyzed the data; J.C.-C. and C.G.-G. wrote the paper. All authors have read and agreed to the published version of the manuscript.

Funding: This work has been conducted within the framework of "Sistemas de mantenimiento industrial" project (Ref. 20140432) and the CONDAP project "Digital skills for workplace mentors in construction sector apprenticeships" funded by the European Commission within the Key Action 2: Cooperation for innovation and the exchange of good practices, reference number 2018-1-UK01KA202-048122.

Institutional Review Board Statement: Not applicable.

Informed Consent Statement: Not applicable.

Data Availability Statement: Not applicable.

Acknowledgments: We want to thank the participation and dedication of all the people involved in this research, most of them maintenance engineering professionals, as well as the participating companies.

Conflicts of Interest: The authors declare no conflict of interest.

\section{References}

1. Coakes, E.; Amar, A.; Granados, M.L. Knowledge management, strategy, and technology: A global snapshot. J. Enterp. Inf. Manag. 2010, 23, 282-304. [CrossRef]

2. Kalkan, V.D. An overall view of knowledge management challenges for global business. Bus. Process. Manag. J. 2008, 14, 390-400. [CrossRef]

3. Da, X.L.; Xu, K.E.; Ling Li, L. Industry 4.0: State of the art and future trends. Int. J. Prod. Res. 2018, 56, $2941-2962$. 
4. Marshall, N.; Brady, T. Knowledge management and the politics of knowledge: Illustrations from complex products and systems. Eur. J. Inf. Syst. 2001, 10, 99-112. [CrossRef]

5. Lundvall, B.; Nielsen, P. Knowledge management and innovation performance. Int. J. Manpow. 2007, 28, 207-223. [CrossRef]

6. Cárcel-Carrasco, F.-J.; Cárcel-Carrasco, J.-A.; Peñalvo-López, E. Factors in the Relationship between Maintenance Engineering and Knowledge Management. Appl. Sci. 2020, 10, 2810. [CrossRef]

7. Tan, C.L.; Nasurdin, A. Human Resource Management Practices and Organizational Innovation: Assessing the Me-diating Role of Knowledge Management Effectiveness. Electron. J. Knowl. Manag. 2011, 9, 155-167.

8. Lichtenthaler, U. Intellectual property and open innovation: An empirical analysis. Int. J. Technol. Manag. 2010, 52, 372. [CrossRef]

9. Lim, K.; Chesbrough, H.; Ruan, Y. Open innovation and patterns of R\&D competition. Int. J. Technol. Manag. 2010, 52, 295. [CrossRef]

10. Lee, S.; Park, G.; Yoon, B.; Park, J. Open innovation in SMEs-An intermediated network model. Res. Policy 2010, 39, 290-300. [CrossRef]

11. González-Sánchez, R.; García-Muiña, F.E. Innovación abierta: Un modelo preliminar desde la gestión del conocimiento. Intang Cap. 2011, 7, 82-115. [CrossRef]

12. Wilkesmann, M.; Wilkesmann, U. Industry 4.0-Organizing routines or innovations? Vine J. Inf. Knowl. Manag. Syst. 2018, 48, 238-254. [CrossRef]

13. Yang, L. Industry 4.0: A survey on technologies, applications and open research issues. J. Ind. Inf. Integr. 2017, 6, 1-10. [CrossRef]

14. Isworowati, D.A.; Muhammad, F.; Kurniawati, A.; Kurniawan, M.T. Knowledge Management System for Maintenance Activity: Case Study at the Maintenance Depart-ment of XYZ Corporation. In Proceedings of the IEEE International Conference on Industrial Engineering and Engineering Management (IEEM), Macao, China, 18 December 2019; pp. 139-143.

15. Cárcel-Carrasco, F.J.; Rodríguez-Mendez, M.R. Industrial maintenance and tacit knowledge: An introduction about its incidence. DYNA Manag. 2013, 1, 15. [CrossRef]

16. Manesh, M.F.; Pellegrini, M.M.; Marzi, G.; Dabić, M. Knowledge Management in the Fourth Industrial Revolution: Mapping the Literature and Scoping Future Avenues. IEEE Trans. Eng. Manag. 2021, 68, 289-300. [CrossRef]

17. Pokojski, J.; Oleksiński, K.; Pruszyński, J. Conceptual and detailed design knowledge management in customized productionIndustrial perspective. J. Comput. Des. Eng. 2019, 6, 479-506. [CrossRef]

18. Emmanouilidis, C.; Pistofidis, P.; Bertoncelj, L.; Katsouros, V.; Fournaris, A.P.; Koulamas, C.; Ruiz-Carcel, C. Enabling the human in the loop: Linked data and knowledge in industrial cyber-physical systems. Annu. Rev. Control. 2019, 47, 249-265. [CrossRef]

19. Wan, S.; Li, D.; Gao, J.; Li, J. A knowledge based machine tool maintenance planning system using case-based reasoning tech-niques. Robot. Comput. Integr. Manuf. 2019, 58, 80-96. [CrossRef]

20. Bravo-ibarra, E.; Herrera, L. Capacidad de innovación y configuración de recursos organizativos. Intang. Cap. 2009, 5, 301-320.

21. Griffiths, P.; Remenyi, D. Aligning Knowledge Management with Competitive Strategy: A Framework. Electron. J. Knowl. Manag. 2008, 6, 125-134.

22. Argote, L.; Ingram, P. Knowledge trasnfer: A basis for competitive advantage in firms. Organ. Behav. Hum. Decis. Process. 2000, 82, 150-169. [CrossRef]

23. Claver, E.; Zaragoza, P. La dirección de recursos humanos en las organizaciones inteligentes. Una evidencia empírica desde la dirección del conocimiento. Investig. Eur. Dir. Econ. Empresa 2007, 13, 55-73.

24. Ruiz-Sarmiento, J.; Monroy, J.; Moreno, F.-A.; Galindo, C.; Bonelo, J.-M.; Gonzalez-Jimenez, J. A predictive model for the maintenance of industrial machinery in the context of industry 4.0. Eng. Appl. Artif. Intell. 2020, 87, 103289. [CrossRef]

25. Ghobakhloo, M.; Fathi, M. Corporate survival in Industry 4.0 era: The enabling role of lean-digitized manufacturing. J. Manuf. Technol. Manag. 2019, 31, 1-30. [CrossRef]

26. Çınar, Z.M.; Nuhu, A.A.; Zeeshan, Q.; Korhan, O.; Asmael, M.; Safaei, B. Machine Learning in Predictive Maintenance towards Sustainable Smart Manufacturing in Industry 4.0. Sustainability 2020, 12, 8211. [CrossRef]

27. Jasiulewicz-Kaczmarek, M.; Legutko, S.; Kluk, P. Maintenance 4.0 technologies-new opportunities for sustainability driven maintenance. Manag. Prod. Eng. Rev. 2020, 11. [CrossRef]

28. Zonta, T.; da Costa, C.A.; da Rosa Righi, R.; de Lima, M.J.; da Trindade, E.S.; Li, G.P. Predictive maintenance in the Industry 4.0: A systematic literature review. Comput. Ind. Eng. 2020, 150, 106889. [CrossRef]

29. Ceruti, A.; Marzocca, P.; Liverani, A.; Bil, C. Maintenance in aeronautics in an Industry 4.0 context: The role of Augmented Reali-ty and Additive Manufacturing. J. Comput. Des. Eng. 2019, 6, 516-526. [CrossRef]

30. Schumacher, A.; Nemeth, T.; Sihn, W. Roadmapping towards industrial digitalization based on an Industry 4.0 maturity model for manufacturing enterprises. Procedia Cirp 2019, 79, 409-414. [CrossRef]

31. Bousdekis, A.; Lepenioti, K.; Apostolou, D.; Mentzas, G. Decision Making in Predictive Maintenance: Literature Review and Re-search Agenda for Industry 4.0. IFAC-PapersOnLine 2019, 52, 607-612. [CrossRef]

32. Lee, S.M.; Lee, D.; Kim, Y.S. The quality management ecosystem for predictive maintenance in the Industry 4.0 era. Int. J. Qual. Innov. 2019, 5, 4. [CrossRef]

33. Patalas-Maliszewska, J.; Kłos, S. An Approach to Supporting the Selection of Maintenance Experts in the Context of Industry 4.0. Appl. Sci. 2019, 9, 1848. [CrossRef]

34. Sang, G.M.; Xu, L.; de Vrieze, P.T.; Bai, Y.; Pan, F. Predictive Maintenance in Industry 4.0. In Proceedings of the ICIST 2020: 10th Interna-tional Conference on Information Systems and Technologies, Lecce, Italy, 4-5 June 2020. 
35. Bag, S.; Pretorius, J.H.C. Relationships between industry 4.0, sustainable manufacturing and circular economy: Proposal of a research framework. Int. J. Organ. Anal. 2020. [CrossRef]

36. Pawlowski, J.; Bick, M. The Global Knowledge Management Framework: Towards a Theory for Knowledge Management in Globally Distributed Settings. Electron. J. Knowl. Manag. 2012, 10, 92-108.

37. Nonaka, I. The Knowledge-Creating Company. Harv. Bus. Rev. 1991, 68, 96-104.

38. Nonaka, I.; Takeuchi, H. The Knowledge Creating Company: How Japanese Companies Create the Dynamics of Innovation; Oxford University Press: Oxford, UK, 1995.

39. Garud, R.; Nayyar, P. Transformative capacity: Continual structuring by intemporal technology transfer. Strateg. Manag. J. 1994, 15, 365-385. [CrossRef]

40. Kogut, B.; Zander, U. Knowledge of the Firm, Combinative Capabilities, and the Replication of Technology. Organ. Sci. 1992, 3, 383-397. [CrossRef]

41. Foss, N.J.; Knudsen, C.; Montgomery, C.A. An Exploration of Common Ground: Integrating Evolutionary and Strategic Theories of the Firm. In Resource-Based and Evolutionary Theories of the Firm; Montgomery, C., Ed.; Springer: Boston, MA, USA, 1995; pp. $1-17$.

42. Lloira, M.; Peris, F. Mecanismos de coordinación estructural, facilitadores y creación de conocimiento. Rev. Eur. Dir. Econ. Empresa 2007, 16, 29-46.

43. Hoelzle, K.; Gemuenden, H.G. Cultural vs. structural aspects of Open Innovation-How to implement Open Innovation. In Proceedings of the TUHH User and Open Innovation Workshop 2009, Hamburg, Germany, 3-5 June 2009; University of Hamburg: Hamburg, Germany, 2009.

44. Camelo, C.; García, J.; Sousa, E. Facilitadores de los procesos de compartir conocimiento y su influencia sobre la innovación. Cuad. Econ. Dir. Empresa 2010, 42, 35-74. [CrossRef]

45. Yahya, S.; Goh, W. Managing human resources toward achieving knowledge management. J. Knowl. Manag. 2002, 6, 457-468. [CrossRef]

46. Heising, C. IEEE Recommended Practice for the Design of Reliable Industrial and Commercial Power Systems; IEEE Inc.: New York, NY, USA, 2007.

47. Koval, D.; Zhang, X.; Prost, J.; Coyle, T.; Arno, R.; Hale, R. Reliability methodologies applied to the IEEE Gold Book standard network. IEEE Ind. Appl. Mag. 2003, 9, 32-41. [CrossRef]

48. Wang, W.; Loman, J.; Arno, R.; Vassiliou, P.; Furlong, E.; Ogden, D. Reliability Block Diagram Simulation Techniques Applied to the IEEE Std. 493 Standard Network. IEEE Trans. Ind. Appl. 2004, 40, 887-895. [CrossRef]

49. Yañez, M.; Gómez de la Vega, H.; Valbuena, G. Ingeniería de Confiabilidad y Análisis Probabilístico de Riesgo; Reliability and Risk Management S.A: Caracas, Venezuela, 2004; ISBN 980-12-12-01116-9.

50. Cacique, J. Diseño de un Programa Para Calcula la Confiabilidad en un Sistema de Distribución de Energía Eléctrica; UNEXPO: Venezuela, South America, 2007; p. 138.

51. Baeza, G.; Rodríguez, P.; Hernández, J. Evaluación de confiabilidad de sistemas de distribución eléctrica en desregulación. Rev. Fac. Ing. Chile 2003, 11, 33-39. [CrossRef]

52. McGranaghan, M. Quantifying Reliability and Service Quality for Distribution Systems. IEEE Trans. Ind. Appl. 2007, 43, 188-195. [CrossRef]

53. Altmann, C. El Análisis de Causa Raíz, como herramienta en la mejora de la Confiabilidad. In Proceedings of the 2do Congreso Uruguayo de Mantenimiento, Gestión de Activos y Confiabilidad, Montevideo, Uruguay, 16-18 August 2006.

54. Amendola, L. Modelos mixtos de Confiabilidad Projet Managament; PMM Institute For Learning: Alboraya, Spain, 2016; ISBN 978-84-943897-3-3.

55. Amendola, L. Estrategias y Técnicas en la Dirección y Gestión de Proyectos. In ProjetManagament; Universitat Politècnica de València: Valencia, Spain, 2004; ISBN 84-9705-522-5.

56. Tavares, L. Administración moderna de Mantenimiento; Novo Polo Publicacoes: Rio De Janeiro, Brasil, 2004.

57. Wiig, K.M. Integrating Intellectual Capital and Knowledge Management. Long Range Plan. 1997, 30, 3. [CrossRef]

58. Bueno, E. La sociedad del conocimiento: Un nuevo espacio de aprendizaje de las personas y organizaciones, en La Sociedad del Conocimiento. Rev. Valencia. Estud. Autonómicos 2001, 21-42.

59. Corbin, J.; Strauss, A. Basics of Qualitative Research: Techniques and Procedures for Developing Grounded Theory; Sage Publications: London, UK, 2015; ISBN 978-1-4129-9746-1.

60. Charmaz, K. Constructing Grounded Theory: A Practical Guide through Qualitative Analysis; SAGE: London, UK, 2006.

61. Glaser, B.G.; Strauss, A.L. The Discovery of Grounded Theory; Aldine deGruyter: New York, NY, USA, 1967.

62. Pace, S. A grounded theory of the flow experiences of Web users. Int. J. Hum. Comput. Stud. 2004, 60, 327-363. [CrossRef]

63. Cutcliffe, J.R. Adapt or adopt: Developing and transgressing the methodological boundaries of grounded theory. J. Adv. Nurs. 2005, 51, 421-428. [CrossRef]

64. Martínez Carazo, P.C. El método de estudio de caso. Estrategia metodológica de la investigación científica. Rev. Científica Pensam. Gestión 2006, 20, 165-193.

65. Gibbs, G.R. Media Review: Atlas.ti Software to Assist with the Qualitative Analysis of Data. J. Mix. Methods Res. 2007, 1, 103-104. [CrossRef] 
66. Hwang, S. Utilizing Qualitative Data Analysis Software: A review of ATLAS.ti. Soc. Sci. Comput. Rev. 2007, $26,519-527$. [CrossRef]

67. Lewis, R.B. NVivo 2.0 and ATLAS.ti 5.0: A Comparative Review of Two Popular Qualitative Data-Analysis Programs. Field Methods 2004, 16, 439-464. [CrossRef] 